\title{
Signs and symptoms related to inhalation of surgical smoke in the nursing team
}

\author{
Sinais e sintomas relacionados à inalação da fumaça cirúrgica na equipe de enfermagem
} Signos y síntomas relacionados con la inhalación del humo quirúrgico en el equipo de enfermería

Ana Claudia Saito ${ }^{1}$ Amanda Salles Margatho ${ }^{2}$ Aryane Apolinario Bieniek ${ }^{1}$ (D) Nathanye Crystal Stanganelli ${ }^{1}$ Renata Perfeito Ribeiro ${ }^{1}$

1. Universidade Estadual de Londrina. Londrina, PR, Brasil

2. Universidade de São Paulo. Ribeirão Preto, SP, Brasil
Corresponding Author:

Amanda Salles Margatho.

E-mail: amandamargatho@usp.br.

Submitted on $10 / 03 / 2018$

Accepted on 02/09/2019.

DOI: 10.1590/2177-9465-EAN-2018-0292

\section{Abstract}

Objective: To compare the prevalence of signs and symptoms related to inhalation of surgical smoke among surgical technologists and non-surgical technologists nursing professionals. Method: A cross-sectional study with 46 professionals from a university hospital. To evaluate the prevalence, an instrument with signs/symptoms related to the inhalation of electrocautery smoke was used. To verify the comparison between the prevalence of signs/symptoms, the Fisher's exact test was performed. Results: Higher prevalence of all signs/symptoms among surgical technologists, with a statistically significant difference between the act of instrumenting with the presence of at least one signs/symptoms related to inhalation of surgical smoke $(p=0.01)$; eye irritation $(p=0.02)$; irritation of nasal mucosa and oral cavity $(p=0.03)$; headache $(p=0.04)$. Conclusion: The presence of problems related to surgical smoke in nursing workers elicits more attention. Implications for practice: Health units must be aware of the risk of such exposure and take measures to preventing it.

Keywords: Electrocautery; Smoke; Signs and Symptoms; Occupational Health

\section{Resumo}

Objetivo: Comparar a prevalência de sinais e sintomas relacionados à inalação da fumaça cirúrgica entre trabalhadores de enfermagem instrumentadores e não-instrumentadores. Método: Estudo transversal realizado com 46 trabalhadores em um hospital universitário. Para avaliação da prevalência, foi utilizado um instrumento com sinais e sintomas relacionados à inalação da fumaça do eletrocautério. Para a comparação entre a prevalência dos sinais/sintomas, realizou-se o teste exato de Fisher. Resultados: Maior prevalência de todos os sinais/sintomas entre profissionais que instrumentam, com diferença estatisticamente significante entre o ato de instrumentar com a presença de pelo menos um sinal/sintoma relacionado à inalação da fumaça cirúrgica $(p=0,01)$; irritação nos olhos $(p=0,02)$; da mucosa nasal e cavidade oral $(p=0,03)$; cefaleia $(p=0,04)$. Conclusão: A presença de problemas relacionados à fumaça cirúrgica em instrumentadores suscita maior atenção. Implicações para a prática: As unidades de saúde devem tomar ciência do risco dessa exposição e adotar medidas de prevenção a este risco.

Palavras-chave: Eletrocautério; Fumaça; Sinais e Sintomas; Saúde do Trabalhador.

\section{Resumen}

Objetivo: Comparar la prevalencia de signos y síntomas relacionados a la inhalación del humo quirúrgico entre trabajadores de enfermería instrumentadores y no-instrumentadores. Método: Estudio transversal realizado con 46 trabajadores en un hospital universitario. Para evaluación de la prevalencia, se utilizó un instrumento con signos/síntomas relacionados con la inhalación de humo del electrocauterio. Para la comparación entre prevalencia de signos/síntomas, fue realizada la prueba exacta de Fisher. Resultados: Mayor prevalencia de todos los signos/síntomas entre instrumentadores, con diferencia estadísticamente significante entre el acto de instrumentar con la presencia de por lo menos un signo/síntomas relacionado con la inhalación del humo quirúrgico ( $p=0,01)$; irritación en los ojos $(p=0,02)$; de mucosa nasal y cavidad oral $(p=0,03)$; cefalea $(p=0,04)$. Conclusión: La presencia de problemas relacionados al humo quirúrgico en instrumentadores suscita mayor cuidado. Implicaciones para la práctica: Unidades de salud deben considerar los riesgos de esta exposición y adoptar medidas de prevención.

Palabras clave: Electrocauterio; Humo; Signos y Síntomas; Salud Laboral. 


\section{INTRODUCTION}

The surgical center is considered a complex unit in relation to its specificity, which brings about risks inherent to the work activity for the staff of this workplace. ${ }^{1}$ The incorporation of technology in the surgical practice is essential to minimize risks to patients and facilitate the procedures performed. An example of this technology is electrocautery, which is widely used for cutting and coagulating tissues and vessels; this reduces surgical time, reduces intraoperative bleeding and improves visibility of the operative field. ${ }^{2}$

However, tissue cauterization performed by electrocautery generates products such as water vapor and surgical smoke, in which aromatic polycyclic hydrocarbons, hydrogen cyanide, formaldehyde, carbon monoxide, among others ${ }^{3}$ were identified, being some of these compounds considered carcinogenic. ${ }^{4}$

During surgical procedures, surgical smoke is inhaled by professionals exposed to the use of electrocautery. Due to the size of the particles contained in this smoke, ranging from $200 \mathrm{mi}-$ crometers to units smaller than 10 nanometers, inhaled components can deposit into the lungs causing respiratory discomfort. ${ }^{5}$ Long-term exposure to surgical smoke may favor development of cancer, neurological diseases, heart and respiratory diseases. ${ }^{4}$

The symptoms resulting from inhalation of surgical smoke, described in the literature are: eye irritation, headache, nausea and vomiting, asthma, chronic bronchitis, nasopharyngeal lesions, irritation of the nasal mucosa and oral cavity, burning in the pharynx, weakness, fatigue, nasal congestion, sensation of a foreign body in the throat and sneezing. ${ }^{2,6-7}$

Electrocautery smoke is considered a risk for exposed workers, including surgical instrumentators. ${ }^{8}$ These professionals may be more exposed to the risk of developing signs and symptoms because they inhale surgical smoke, since they work near the operative field, being closer to the source of smoke.

Substances contained in the surgical smoke produced by the electrocautery cause damage to the health professionals in proportion to the exposure, since they have cumulative effects and require a prolonged follow-up of these exposed workers. ${ }^{3}$ The consequences of exposure to surgical smoke are influenced by factors such as surgical technique, type of procedure, pathology of the target tissue, type of energy supplied by the equipment, power levels used in it, among others. ${ }^{7}$ The manifestations and consequences of inhalation of surgical smoke in health professionals have received great attention, being discussed by authors and reference institutions for perioperative nursing. ${ }^{2-3,6-8,9-11}$

However, it is necessary to develop research that increase the level of evidence on the subject, which evaluate the signs and symptoms related to the inhalation of surgical smoke in each group of workers, since there are still few studies that indicate this prevalence in surgical technologists.

Therefore, the present study has the objective of comparing the prevalence of signs and symptoms related to inhalation of surgical smoke among surgical technologists and non-surgical technologists nursing professionals.

\section{METHOD}

This is a cross-sectional study carried out in the surgical center of a university hospital located in the state of Paraná, which has seven surgical rooms and performs various medical specialties, such as general surgery, urology, child surgery, neurology, vascular, thoracic, cardiology, gynecology and obstetrics, orthopedics, ophthalmology, plastic surgery, otolaryngology, oral and maxillofacial, digestive tract surgery, among others. Approximately 20 surgical procedures are performed daily and electrocautery is used in most surgeries.

There are 49 professionals in the nursing team of this surgical center. Of these, 10 are nurses and 39 are technicians and nursing assistants. Those who perform the activity are understood as surgical technologists, being either nursing technicians or assistants, totaling 28 professionals in this study.

Regarding the time that each professional stays in the operating rooms, it is seen that the nurses perform activities of management of the care attending to the patient and managerial activities of the surgical center, besides being responsible for several operating rooms; in this way they do not remain for the entire surgical time inside the room. The surgical and non-surgical technologists and assistants participate from the reception of the patient in the room until he/she is sent to the post-anesthetic care unit, and the surgical technologists act closer to the operative field and, consequently, are more exposed to smoke surgery.

Related to the eligibility criteria, we included workers from the nursing team of the surgical center acting in the period of data collection. Those who are on medical leave, vacation and/or work leave were excluded. Three were excluded from the study because they were on work leave, and no professional refused to participate in the study. Of the excluded, one was a surgical technologists and two were technicians who did not perform surgical instrumentation. Therefore, the sample consisted of 46 workers.

Data collection took place between November 2016 and April 2017. Participants were recruited by the researcher responsible for collecting data who verified the possibility of the professional meeting the eligibility criteria. If the professional was qualified, he/she would be informed about the characteristics, objectives of the study and oriented regarding his/her voluntary participation; then he/she was invited to take part in the research and asked for his/her consent. As there was no refusal, all eligible professionals signed the Free and Informed Consent Form.

For the collection of data, a collection instrument was elaborated which was previously submitted to the evaluation of content and appearance by three judges. This collection was done individually with the workers in a reserved room, in the own surgical center, during the working day and according to availability. The data collection instrument was delivered to the research subject who would complete and return it to the responsible researcher at the end.

Sociodemographic and occupational variables were collected such as: age (in years); working time in surgical center (in years); gender (female and male); occupation (nurse, technician 
and nursing assistant) and perform surgical instrumentation (yes, no).

Variables related to the presence of signs and symptoms related to the inhalation of electrocautery smoke were dichotomic with "yes" or "no" answers. The variables were: sensation of a foreign body in the throat, burning in the pharynx, presence of nasopharyngeal lesions, nausea and/or vomiting, nasal congestion, headache, eye irritation, irritation of the nasal mucosa and oral cavity, sneezing, weakness, fatigue and asthmatic crises. ${ }^{2,6-7}$

For workers who presented some sign or symptom, an item of the data collection instrument questioned whether he/she believed there was a relation to the type of profession performed. The professional's knowledge about the subject was also evaluated and if he/she was aware of the effects of exposure to surgical smoke. These variables were dichotomic with "yes" or "no" answers.

Statistical analysis was performed using the software SPSS (Statistical Package for the Social Science), version 25.0 for Windows. Simple frequency descriptive analyses were performed for the nominal or categorical variables, of central tendency (average) and dispersion (standard deviation, minimum and maximum values) for the continuous variables. To compare the prevalence of signs and symptoms related to the inhalation of surgical smoke in surgical technologists of the surgical center nursing team, the Fisher's exact test was performed. The level of significance was set at $0.05(a<0.05)$.

The development of the study was approved by the Ethics Committee on Research in Human Beings, under Opinion No. 1,141,236 - CAAE 46229915.0.0000.5231.

\section{RESULTS}

Table 1 presents the sociodemographic characterization, the time performing in the surgical center and the occupation of the nursing staff of the surgical center.

Table 2 shows the prevalence of signs and symptoms related to the inhalation of surgical smoke from the surgical center's nursing staff.

The results showed that the prevalence of all signs and symptoms was higher among those who act as surgical technologist; however, there was a statistically significant difference between the act of instrumenting and the signs and symptoms: eye irritation $(p=0.02)$; irritation of the nasal mucosa and oral cavity $(p=0.03)$ and headache $(p=0.04)$. Signs and symptoms of nasal congestion and sneezing presented one of the highest prevalence among the surgical technologist professionals $(n=9)$ compared to those who do not act as surgical technologist $(n=2)$, but without a statistically significant difference $(p=0.06)$. None $(n=0)$ of the professionals of the nursing team had asthmatic attacks.

Of the nursing professionals that participated in this study, $31(67.4 \%)$ had a signs or symptoms related to the inhalation of surgical smoke, and 15 (32.6\%) did not present any signs or symptoms. Of those who presented, $83.9 \%$ reported being related to the type of profession they carry out. Of the workers interviewed, 20 (43.5\%) were unaware of the effects of exposure
Table 1. Sociodemographic characteristics, time performing and occupation of the nursing staff of the surgical center. Paraná, Brazil, 2017.

\begin{tabular}{|c|c|c|}
\hline Variables & $\begin{array}{c}\text { Surgical } \\
\text { technologist } \\
n=27\end{array}$ & $\begin{array}{c}\text { Non-surgical } \\
\text { technologist } n= \\
19\end{array}$ \\
\hline $\begin{array}{l}\text { Age in years } \\
\text { Average (SD)* }\end{array}$ & $44.0(7.7)$ & $46.0(8.1)$ \\
\hline Minimum & 29 & 25 \\
\hline Maximum & 58 & 56 \\
\hline $\begin{array}{l}\text { Working timein } \\
\text { years } \\
\text { Average (SD)* }\end{array}$ & $15.0(9.1)$ & $11.0(9.6)$ \\
\hline Minimum & 0 & 0 \\
\hline Maximum & 35 & 31 \\
\hline \multicolumn{3}{|l|}{$\begin{array}{l}\text { Gender } \\
\text { n (\%) }\end{array}$} \\
\hline Female & 21 (45.7) & $16(34.8)$ \\
\hline Male & $6(13.0)$ & $3(6.5)$ \\
\hline \multicolumn{3}{|l|}{$\begin{array}{l}\text { Occupation } \\
n(\%)\end{array}$} \\
\hline Nurses & $0(0)$ & $10(21.7)$ \\
\hline $\begin{array}{l}\text { Nursing technicians } \\
\text { and assistants }\end{array}$ & $27(58.7)$ & 9 (19.6) \\
\hline
\end{tabular}

Table 2. Comparison of the prevalence of signs and symptoms related to inhalation of surgical smoke in surgical technologists of the surgical center's nursing staff. Paraná, Brazil, 2017.

\begin{tabular}{lccc}
\hline Variables & $\begin{array}{c}\text { Surgical } \\
\text { technologist } \\
\mathrm{n}=27 \mathrm{n}(\%)\end{array}$ & $\begin{array}{c}\text { Non-surgical } \\
\text { technologist } \\
\mathrm{n}=19 \mathrm{n}(\%)\end{array}$ & p-value* \\
\hline Eye irritation & $11(23.9)$ & $2(4.3)$ & 0.02 \\
Yes & $16(34.8)$ & $17(37.0)$ & \\
No & & & \\
Irritation of the & & & \\
nasal mucosa & & $1(2.2)$ & \\
and oral cavity & $8(17.4)$ & $18(39.1)$ & 0.04 \\
Yes & $19(41.3)$ & & \\
No & & $3(6.5)$ & \\
Headache & $12(26.1)$ & $16(34.8)$ & \\
Yes & $15(32.6)$ & & \\
No & & $17(37.0)$ & \\
Nasal conges- & & & \\
tion & $9(19.6)$ & & \\
Yes & $18(39.1)$ & & \\
No & & & \\
\hline
\end{tabular}




\begin{tabular}{|c|c|c|c|}
\hline Variables & $\begin{array}{c}\text { Surgical } \\
\text { technologist } \\
n=27 n(\%)\end{array}$ & $\begin{array}{c}\text { Non-surgical } \\
\text { technologist } \\
n=19 n(\%)\end{array}$ & $p$-value* \\
\hline Sneezing & & & 0.06 \\
\hline Yes & 9 (19.6) & $2(4.3)$ & \\
\hline No & 18 (39.1) & $17(37.0)$ & \\
\hline $\begin{array}{l}\text { Sensation of } \\
\text { foreign body in } \\
\text { the throat }\end{array}$ & & & 0.17 \\
\hline Yes & 5 (10.9) & $1(2.2)$ & \\
\hline No & $22(47.8)$ & 18 (39.1) & \\
\hline $\begin{array}{l}\text { Nasopharyngeal } \\
\text { lesions }\end{array}$ & & & 0.30 \\
\hline Yes & $1(2.2)$ & 0 & \\
\hline No & $26(56.5)$ & 19 (41.3) & \\
\hline $\begin{array}{l}\text { Burning in the } \\
\text { pharynx }\end{array}$ & & & 0.40 \\
\hline Yes & $7(15.2)$ & $3(6.5)$ & \\
\hline No & $20(43.5)$ & $16(34.8)$ & \\
\hline $\begin{array}{l}\text { Nausea and/or } \\
\text { vomiting }\end{array}$ & & & 0.48 \\
\hline Yes & $3(6.5)$ & $1(2.2)$ & \\
\hline No & $24(52.2)$ & 18 (39.1) & \\
\hline Weakness & & & 0.77 \\
\hline Yes & $2(4.3)$ & $1(2.2)$ & \\
\hline No & $25(54.3)$ & 18 (39.1) & \\
\hline Fatigue & & & 0.95 \\
\hline Yes & $3(6.5)$ & $2(4.3)$ & \\
\hline No & $24(52.2)$ & $17(37.0)$ & \\
\hline
\end{tabular}

* Fisher's exact test $p$-value.

to surgical smoke generated by the use of electrocautery, and $26(56.5 \%)$ had some knowledge on the subject.

There was a higher prevalence of signs and symptoms among the professionals who are surgical technologists with a statistically significant difference between the act of instrumenting and the presence of, at least, one of the signs and symptoms related to the inhalation of surgical smoke $(p=0.01)$; Table 3 presents these results.

\section{DISCUSSION}

Regarding the worktime in the surgical center, a survey conducted in the United States found that practically $70 \%$ of the nurses had more than 16 years of experience, a result close to that found in the present study ${ }^{11}$, as well as, in Turkey, $23.5 \%$ of respondents reported operating in the surgical center area for more than 15 years. ${ }^{10}$
Table 3. Comparison of the prevalence of signs and symptoms related to the inhalation of surgical smoke in technologists of the surgical center nursing team. Paraná, Brazil, 2017.

\begin{tabular}{lccc}
\hline Variables & $\begin{array}{c}\text { Surgical } \\
\text { technologist } \\
\mathrm{n}=27 \mathrm{n}(\%)\end{array}$ & $\begin{array}{c}\text { Non-surgical } \\
\text { technologist } \mathrm{n}= \\
19 \mathrm{n}(\%)\end{array}$ & p-value* \\
\hline $\begin{array}{l}\text { Presented } \\
\text { any sign or } \\
\text { symptom }\end{array}$ & & & 0.01 \\
Yes & $11(23.9)$ & $2(4.3)$ & \\
No & $16(34.8)$ & $17(37.0)$ &
\end{tabular}

* Fisher's exact test $\mathrm{p}$-value.

In Brazil, the nursing team that acts in the surgical center is composed of nurses, perfusionist nurses, nursing technicians and surgical technologists. Surgical instrumentation is an activity restricted to the professional who performed the course of surgical instrumentation, but even if this is a nursing activity, it is not exclusive to this profession, but the person performing it should be supervised by the unit's technical leader. ${ }^{12}$ In this study, surgical technologists are nursing assistants and technicians (58.7\%).

In relation to the signs and symptoms related to the inhalation of surgical smoke, in a cross-sectional study performed with resident physicians of several surgical specialties, $58 \%$ reported foreign body sensation in the throat, $22 \%$ burning in the pharynx, $4 \%$ nausea and $2 \%$ nasal congestion. ${ }^{2}$ In this study, nasal congestion and nausea and vomiting were found to be more prevalent among surgical technologists, with $6.5 \%$ and $19.6 \%$, respectively.

A research performed with surgical center nurses, medical surgeons and anesthesiologists found that among the group of nurses, the most common symptoms were headache $(48.9 \%)$, cough (48.9\%) and nausea (44.4\%). in the medical group there was a predominance of headache $(58.3 \%)$ followed by other symptoms such as sneezing, irritation, respiratory tract infections, weakness, myalgia, dermatitis, conjunctivitis, anemia, cardiovascular diseases, nasopharyngeal lesions, abdominal pain and vomiting. ${ }^{10}$ All the findings of this study were superior when compared to the present investigation, in which the cough symptom was not found.

In this study, the prevalence of headache was 32.6\%; eye irritation $28.2 \%$; nasal congestion and sneezing $23.9 \%$; irritation of the nasal mucosa and oral cavity $19.6 \%$. The results showed a statistically significant difference between the act of instrumenting and the prevalence of signs and symptoms in the surgical technologist group, mainly eye irritation $(p=0.02)$, irritation of the nasal mucosa and oral cavity $(p=0.03)$, and headache $(p=0.04)$. Nasal congestion and sneezing were close to statistical significance $(p=0.06)$.

This research evidenced a higher prevalence of all signs and symptoms among the professionals who work as surgical technologists; there was a statistically significant difference between 
the act of instrumenting with the presence of at least one of the signs and symptoms related to the inhalation of surgical smoke $(p=0.01)$. After its formation, surgical smoke is rapidly dispersed in surgical rooms; however, in the surgeons' respiratory height, the concentrations of the chemical components of the smoke can be 40 to 100 times greater than in the rest of the environment ${ }^{13}$.

The surgical technologists are the workers that besides the surgeons are very close to the operative field, presenting greater possibility of inhalation of the surgical smoke when compared with the professionals who do not perform this activity, which may explain the statistical significance found in this study. It should be noted that eyes irritation, irritation of the nasal mucosa and oral cavity and headache can have consequences for the worker who performs it in the long term.

A study indicated the precautions used for individual protection by professionals using electrocautery. It was found that $91.1 \%$ of the nurses and $86.1 \%$ of the physicians use common surgical masks. ${ }^{10}$ However, the use of this type of mask does not provide adequate protection for the filtration and protection against the risks inherent in the inhalation of surgical smoke. ${ }^{7}$ Chronic exposure to surgical smoke can transmit to the exposed worker virus and cause cancer, neurological diseases, heart and respiratory diseases that can be prevented by the use of safety devices such as smoke aspirators and appropriate masks. ${ }^{14}$

Despite the recommendation to use filters, smoke aspirators and the use of $\mathrm{N} 95^{9,15}$ masks that protects the worker exposed to the inhalation of the surgical smoke, the incorporation of these appliances is still precarious due to the annoyance related to the noise produced by the device, the use of the mask and non-recognition of inhalation of surgical smoke as a risk. ${ }^{16-17}$

The barriers to adherence are related to the large amount of equipment available in the market, with the resistance of the workers involved and the noise emitted by the equipment. In order to comply with the recommendations regarding protective devices, it is necessary to invest in knowledge and training on the subject, implementation of educational programs and support to leaderships, in order to apply international recommendations for a smoke-free environment. ${ }^{11}$

Investments related to a surgical smoke-free environment are necessary and urgent, as the worrying results of this study show, since $43.5 \%$ of the workers reported not knowing the issue and $67.4 \%$ presented signs and symptoms related to the inhalation of surgical smoke. Investments must extrapolate care with nursing staff workers, and also, for all those exposed to the ills caused by the inhalation of surgical smoke, such as medical residents and surgeons.

The results found in this research cannot be generalized, because it is a cross-sectional study, performed in only one surgical center and the use of convenience sampling.

As a limitation of this study it is considered the small sample size of nursing workers who undergo the inhalation of surgical smoke in this surgical center and it is also necessary to consider that the signs and symptoms reported in the scientific literature related to exposure to surgical smoke can also be regarded as prodromes of other diseases common in the general population.

\section{CONCLUSION AND IMPLICATIONS FOR PRACTICE}

This study showed a greater prevalence of all signs and symptoms among the professionals who work as surgical technologists, since there was a statistically significant difference between the act of instrumenting and the presence of signs and symptoms related to the inhalation of surgical smoke, especially eyes irritation, nasal mucosa and oral cavity irritation and headache.

The presence of signs and symptoms related to surgical smoke in nursing workers raises the need for greater care of these professionals, since they are exposed to the harmful effects caused in the human body and will be exposed in the course of their professional life.

Because the effects related to the inhalation of surgical smoke caused in the human body are cumulative, there is a need for studies that carry out long-term follow-up of exposed workers for a better understanding of the development of the signs and symptoms caused by this inhalation. There is also a need that the units which favor the exposure of workers to the inhalation of surgical smoke, to be aware of the risk of such exposure and to take preventive measures for this risk.

\section{ACKNOWLEDGEMENT}

The authors thank all the Nursing Professionals of the Surgical Center of the University Hospital of the Londrina State University who collaborated with the development of this study.

\section{REFERENCES}

1. Tramontini CC, Galvão CM, Claudio CV, Ribeiro RP, Martins JT. Composition of the electrocautery smoke: integrative literature review. Rev Esc Enferm USP [Internet]. 2016 Feb; [cited $2016 \mathrm{Ju}$ 26]; 50(1):144-53. Available from: http://dx.doi.org/10.1590/S0080623420160000100019

2. Navarro-Meza MC, González-Baltazar R, Aldrete-Rodríguez MG, Carmona-Navarro DE, López-Cardona MG. Respiratory symptoms caused by the use of electrocautery in physicians being trained in surgery in a Mexican hospital. Rev Peru Med Exp Salud Publica [Internet]. 2013 Mar; [cited 2016 Jul 26]; 30(1):41-4. Available from: https://scielosp.org/pdf/rpmesp/2013.v30n1/41-44/es

3. Barret WL, Garber SM. Surgical smoke: a review of the literature. Surg Endosc [Internet]. 2003 Jun; [cited 2016 Jul 26]; 17(6):979-87. Available from: https://doi.org/10.1007/s00464-002-8584-5

4. Choi SH, Kwon TG, Chung SK, Kim TH. Surgical smoke may be a biohazard to surgeons performing laparoscopic surgery. Surg Endosc [Internet]. 2014 Aug; [cited 2016 Jul 26]; 28(8):2374-80. Available from https://doi.org/10.1007/s00464-014-3472-3

5. Eickman IU, Falcy M, Fokuhl I, Rüegger M. International Section of the ISSA on prevention of occupational risks in health services. Surgica smoke: Risks and preventive measures [Internet]. Geneva: Internationa Social Security Association (ISSA); 2012. [cited 2016 Jul 26]. Available from: http://prevencion.umh.es/files/2012/04/2-surgical_smoke.pdf 
6. Ball K. Surgical smoke: is it safe to breathe? Todays Surg Nurse [Internet]. 1996 Sep/Oct; [cited 2016 Jul 26]; 18(5):16-21. Available from: https://www.ncbi.nlm.nih.gov/pubmed/?term=6.\%09Ball+K.+ Surgical+smoke\%3A+is+it+safe+to+breath\%3F.+Todays+Surg+Nur se.+1996

7. Alp E, Bijl D, Bleichrodt RP, Hansson B, Voss A. Surgical smoke and infection control. J Hosp Infect [Internet]. 2006 Jan; [cited 2016 Jul 26]; 62(1):1-5. Available from: https://doi.org/10.1016/j.jhin.2005.01.014

8. Bigony L. Risks Associated with Exposure to Surgical Smoke Plume: a Review of the Literature. AORN J [Internet]. 2007 Dec; [cited 2016 Jul 26]; 86(6):1013-24. Available from: https://doi.org/10.1016/j. aorn.2007.07.005

9. Association of periOperative Registered Nurses (AORN). Guideline for surgical smoke safety. In: Guidelines for Perioperative Practice. Denver: AORN; 2017.

10. Ilce A, Yuzden GE, van Giersbergen MY. The examination of problems experienced by nurses and doctors associated with exposure to surgical smoke and the necessary precautions. J Clin Nurs [Internet]. 2017 Jun; [cited 2018 May 1]; 26(11-12):1555-61. Available from: https://doi.org/10.1111/jocn.13455

11. Ball K. Surgical smoke evacuation guidelines: compliance among perioperative nurses. AORN J [Internet]. 2010 Aug; [cited 2016 Jul 26]; 92(2):e1-e23. Available from: https://doi.org/10.1016/j. aorn.2009.10.026
12. Diretrizes de Práticas em Enfermagem Cirúrgica e Processamento de Produtos para a Saúde. SOBECC/SOBECC Associação Brasileira de Enfermeiros de Centro Cirúrgico, Recuperação Anestésica e Centro de Material e Esterilização. 7a ed. Barueri: Manole/ SOBECC; 2017.

13. Tseng HS, Liu SP, Uang SN, Yang LR, Lee SC, Liu YJ, et al. Cancer risk of incremental exposure to polycyclic aromatic hydrocarbons in electrocautery smoke for mastectomy personnel. World J Surg Oncol [Internet]. 2014 Feb; [cited 2018 Nov 27]; 12:31. Available from: https:// doi.org/10.1186/1477-7819-12-31

14. Schultz L. Can Efficient Smoke Evacuation Limit Aerosolization of Bacteria? AORN J [Internet]. 2015 Jul; [cited 2018 May 1]; 102(1):7-14. Available from: https://doi.org/10.1016/j.aorn.2015.04.023

15. Oberg T, Brosseau LM. Surgical mask filter and fit performance. Am J Infect Control [Internet]. 2008 May; [cited 2018 May 1]; 36(4):276-82. Available from: https://www.ncbi.nlm.nih.gov/pubmed/18455048. DOI: 10.1016/j.ajic. 2007.07.008

16. Edwards BE, Reiman RE. Results of a survey on current surgical smoke control practices. AORN J [Internet]. 2008 Apr; [cited 2018 May 1]; 87(4):739-49. Available from: https://doi.org/10.1016/j.aorn.2007.11.001

17. Romano F, Gustén J, De Antonellis S, Joppolo CM. Electrosurgica Smoke: Ultrafine Particle Measurements and Work Environment Quality in Different Operation Theatres. Int J Environ Res Public Health [Internet] 2017 Jan; [cited 2018 May 1]; 14(2):137. Available from: https://doi. org/10.3390/ijerph14020137 